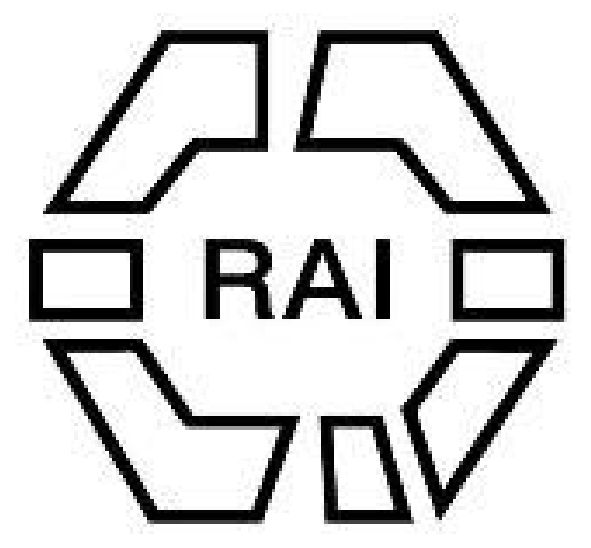

\title{
WILEY
}

\section{Note on a Peruvian Loom of the Chimu Period.}

Author(s): T. A. Joyce

Source: Man, Vol. 22 (Jan., 1922), pp. 1-2

Published by: Royal Anthropological Institute of Great Britain and Ireland

Stable URL: http://www.jstor.org/stable/2839611

Accessed: 25-06-2016 23:16 UTC

Your use of the JSTOR archive indicates your acceptance of the Terms \& Conditions of Use, available at

http://about.jstor.org/terms

JSTOR is a not-for-profit service that helps scholars, researchers, and students discover, use, and build upon a wide range of content in a trusted digital archive. We use information technology and tools to increase productivity and facilitate new forms of scholarship. For more information about JSTOR, please contact support@jstor.org.

Royal Anthropological Institute of Great Britain and Ireland, Wiley are collaborating with JSTOR to digitize, preserve and extend access to Man 


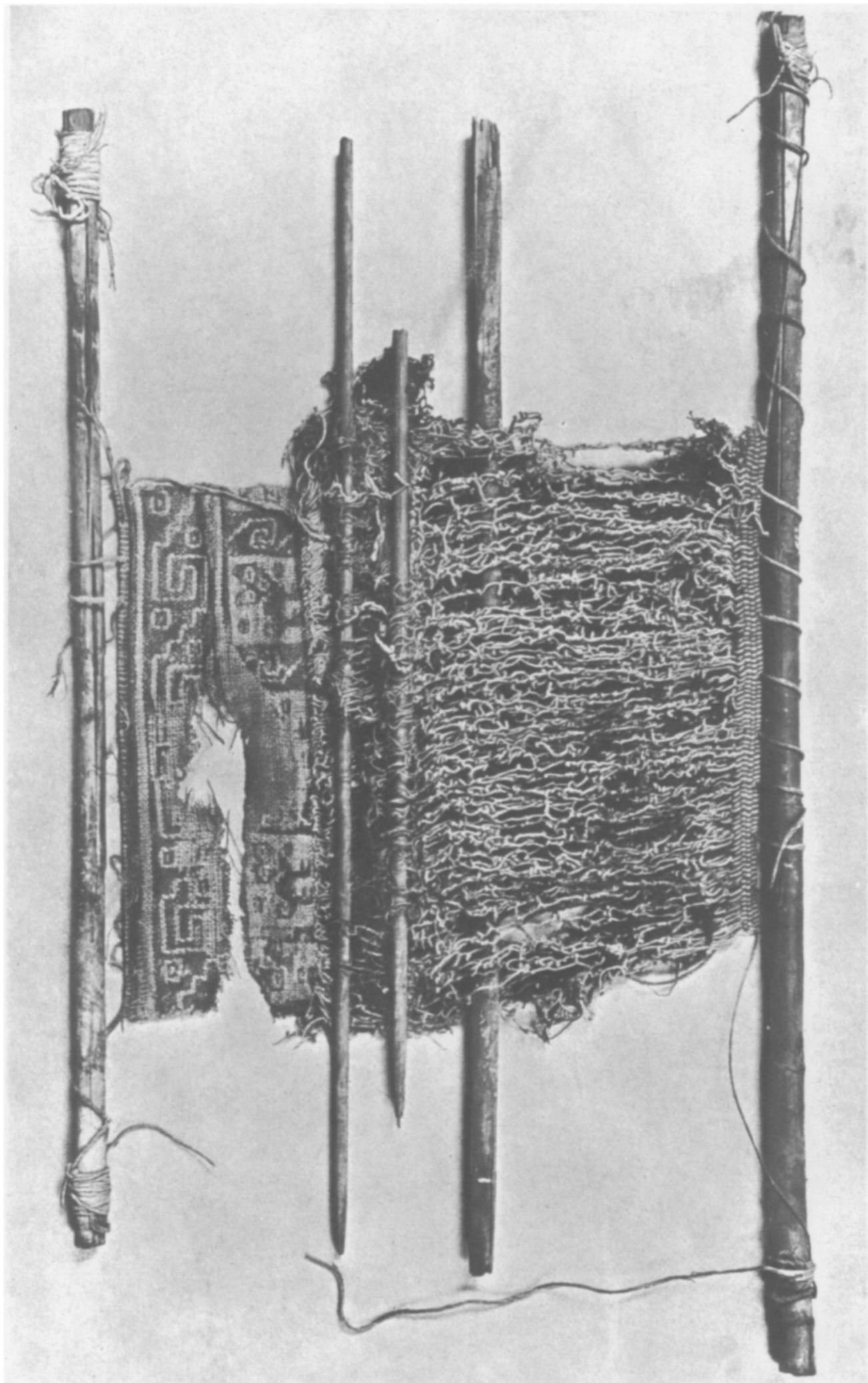

A PERUVIAN LOOM OF THE CHIMU PERIOD.

This content downloaded from 128.163.2.206 on Sat, 25 Jun 2016 23:16:51 UTC All use subject to http://about.jstor.org/terms 


\section{A MONTHLY RECORD OF ANTHROPOLOGICAL SCIENCE. PUBLISHED UNDER THE DIRECTION OF THE ROYAL ANTHROPOLOGICAL INSTITUTE OF GREAT BRITAIN AND IRELAND.}

N.B.-All communications printed in MAN are signed. or initialled by their authors, and the Council of the Institute desires it to be understood that in giving publicity to them it accepts no responsibility for the opinions or statements expressed.

N.B.-MaN, 1921, consists of twelve monthly-published sheets, of at least sixteen pages each, printed in single column; containing "Original Articles" and substantial "Reviews" of recent publications ; all numbered consecutively 1, 2, 3, onwards.

N.B. - Articles published in MAN should be quoted by the year and the reference-number of the article, not by the page-reference; e.g., the article which begins on page 3 should be quoted as MAN, 1922, 2.

\section{ORIGINAL ARTICLES.}

\section{With Plate A.}

\section{Peru: Technology.} (With Plate A.)

In MaN, 1921-106, I figured a Proto-Chimu vase with a painted scene representing a number of weavers engaged in preparing tapestry upon a loom without a heddle. In that article I remarked upon the scarcity of Peruvian looms in museums, and referred to the regrettable fact that practically all were unaccompanied by such details, relating to the circumstances of their discovery, as might enable us to assign them to their proper place in the sequence-dating which is for the moment accepted by archæological students.

The object of the present note is to put on record a pre-Spanish loom from Peru of a type hitherto unchronicled, although its existence could be inferred from the technique of many textile specimens which have been preserved for us. In the previous note, to which I have just referred, I made a number of remarks upon the art of weaving as practised in Peru. It would be a waste of space to repeat them here, but I would remark that the present note loses much of its significance unless it is read as a sequel to its predecessor. The loom which I propose to discuss is figured on Plate A. The dimensions are as follows:-

Length of warp-beam (jointed cane)

Length of cloth-beam (jointed cane)

Total length of loom

Length of warp -

Breadth of textile -

Depth of woven portion -

$$
\begin{aligned}
& \text { - } \quad-\quad-20 \frac{1}{2} \text { in } \\
& \text { - - } \quad-17 \text { in. } \\
& \text { - } \quad-\quad-11 \text { in. } \\
& -\quad-\quad-9 \frac{3}{4} \text { in. } \\
& \text { - - } \quad-8 \text { in. } \\
& \text { - } \quad 2 \frac{3}{4} \mathrm{in} \text {. }
\end{aligned}
$$

The peculiarity of this loom, as compared with other specimens which have survived, lies in the fact that it is adjusted for the manufacture of a double-faced cloth (of which many examples are preserved in museums). It is furnished with two warps and two wefts, white and brown respectively. Each warp, with its corresponding weft, is so manipulated that it passes from one surface of the cloth to the other at regulated intervals; thus producing a pattern which, though identical on each surface, is shown in reversed colours, i.e., brown on white on one side, white on brown on the other. Both warps and both wefts are cotton; the white in the 
natural colour, the brown dyed. The dye has had a deleterious effect upon the brown warp and weft, which has become so fragile that it breaks at the slightest handling, and in one or two places has decayed clean out of the woven fabric.

The method of warping must have been continuous, such as is illustrated in Fig. 6 of Schmidt's monograph,* the double warp, white and brown, being arranged in pairs of warp-threads alternately. A kind of selvage along both warp-beam and cloth-beam was then inserted, consisting of three picks of a stouter weft than

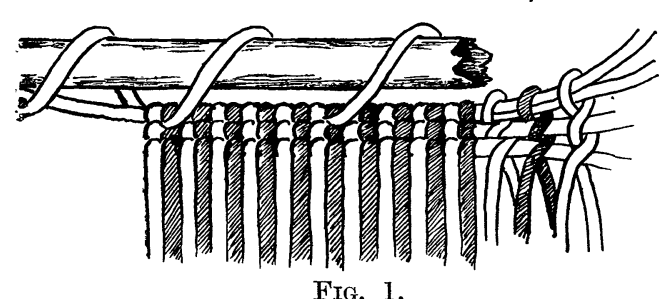
that used in the preparation of the rest of the cloth (and employed in single, double or treble strands), each pair of warp threads being twined between each pick. Fig. 1 shows the schematic arrangement of this "selvage" along the warp-beam. That along the cloth-beam is exactly similar, except that each weft-element consists of a triple strand. From the latter point the weaving proceeded in an ordinary chequer technique. The design is arranged in rectangles, and consists of the wellknown "cat" figure, alternating with the stepped coil. The warps run 28 to the inch, the wefts, 22. For the construction of this double-faced textile, with its elaborate design in reciprocal colours, only two heddles are provided. These heddles, plain wooden rods, serve to raise the odd warp-elements of the white and brown series respectively; they are connected with these warp-elements by a single cotton thread arranged "alternately" $\dagger$ (see Fig. $2 a$ ). In the loom under discussion, the upper heddle manipulates the odd elements of the white warp, and

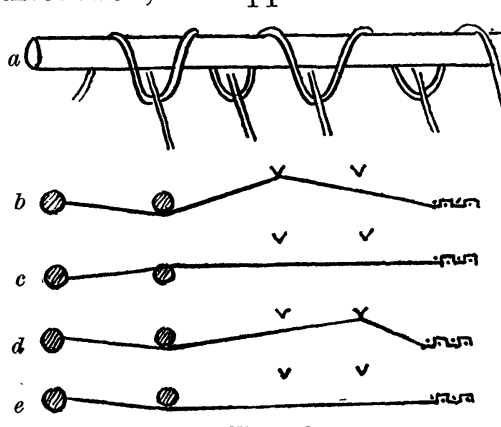

FIG. 2. is reciprocated by the reed shed-stick immediately above, which serves to float the even elements. The lower heddle, which manipulates the odd elements of the brown warp, has no reciprocating shed-stick; but there must surely have been one, which has either fallen out or decayed. However, the operation of the loom, in its present state, is expressed schematically in Figs. $2 b, c, d$, and $e$, which shows four successive picks, the heddles being operated alternately. The necessity of a second shed-stick, reciprocal to the second heddle, is evident.

As regards the date of this loom, information, as in most cases, is lacking. It forms part of a collection of textiles and other objects from various burial grounds in the Departments of Lambayeque, La Libertad and Ancachs, especially in the Pacasmayu Valley, but there is no record to show what finds were immediately associated with it. The collection was formed by the late Dr. de Bolivar, and was acquired by the British Museum in 1907. To judge off-hand, from the meagre information as to locality, from the technique, the material and the low-toned colours, I should place it as belonging to the Chimu period of the Truxillo region, after the conquest of the coast by the Inca, which occurred about 1400 A.D., but before the advent of the Spaniards in the early sixteenth century.

T. A. JOYCE.

* " TTber Altperuanische Gewebe," Baessler-Archiv, Band I, Heft I.

$\dagger$ See H. Ling Roth, "Studies in Primitive Looms," J.R.A.I., Vol. XLVI, pp. 285-286. This method of arranging the heddle-leash is shown by the same authority to be characteristic of. the loom of Indonesia (Illanun and Igorote) and Oceania (Santa Cruz), but, strangely enough, not of the looms of the Uitoto, just across the Andes, nor of the Apache. 